\title{
Use of Lectins to Characterize the Receptor Sites for Bacteriophage PL-1 of Lactobacillus casei
}

\author{
By K. ISHIBASHI, ${ }^{1 *}$ S. TAKESUE, ${ }^{1} \mathrm{~K}$. WATANABE ${ }^{1}$ AND K. OISHI ${ }^{2}$ \\ ${ }^{1}$ Faculty of Pharmaceutical Sciences, Fukuoka University, Fukuoka 814-01, Japan \\ ${ }^{2}$ Institute of Applied Microbiology, University of Tokyo, Tokyo 113, Japan
}

(Received 6 January 1982; revised 8 March 1982)

\begin{abstract}
The polysaccharide (PS) located outside the peptidoglycan layer in Lactobacillus casei ATCC 27092 was found to inhibit the adsorption of PL-1 phage to cell wall preparations without inactivating free phage. Electron microscopic examination of adsorption mixtures showed that the phage were adsorbed to fragments of PS material in a tail-first orientation. Phage did not adsorb to isolated peptidoglycan. The PS was composed of L-rhamnose, D-glucose, Dglucosamine and D-galactosamine, with the hexosamines possibly in $N$-acetylated form. Prior treatment of $L$. casei with Streptomyces haemagglutinin, an anti-human blood group B agglutinin that binds specifically to L-rhamnose, resulted in a concentration-dependent inhibition of phage adsorption. Phage adsorption was inhibited partially by lectins specific for D-glucose and $N$-acetyl-D-glucosamine, but not by lectins specific for $N$-acetyl-D-glucosamine or $N$-acetyl-D-galactosamine. The inhibition of phage adsorption occurred immediately upon the addition of the effective lectins, and was reversed by the addition of the respective lectin inhibitors, $\alpha$-phenyl galactoside or $\alpha$-methyl glucoside. The results indicate that L-rhamnosyl residues are the main determinants of the PL-1 phage receptor sites, while D-glucosyl residues may be involved more indirectly.
\end{abstract}

\section{INTRODUCTION}

The chemical structure of the receptor sites of a Lactobacillus casei phage PL-1, which belongs to the B-group in the classification of Ackerman \& Eisenstark (1974) has been studied. The cell walls of this organism contain a polysaccharide external to the basal peptidoglycan layer; teichoic acids are, however, absent. Therefore, the phage receptor sites are most probably part of the cell surface polysaccharide.

Several lectins bind in a highly specific way to polysaccharide moieties on the surface of various cells (Goldstein \& Staub, 1970; Goldstein \& Misaki, 1970; Reeder \& Ekstedt, 1971; Sharon \& Lis, 1972; Doyle \& Birdsell, 1972; Nicolson \& Baustein, 1972; Osawa, 1975; Liener, 1976; Hamada et al., 1977; Goldstein \& Hayes, 1978; Choy et al., 1979). Therefore, lectins whose binding sugars are known can be used to identify constituent sugars in cell surface polysaccharides. Since both PL-1 phage particles and lectins probably bind to polysaccharides on the cell surface, pretreatment of cells with specific lectins might prevent the adsorption of phages to their receptor sites. This approach has been used to determine which sugars in the cell wall polysaccharide are responsible for the binding of PL-1 phage, using a variety of lectins whose main binding sugars are those found in the wall polysaccharide of Lactobacillus casei ATCC 27092.

\section{METHODS}

Bacteriophage and bacterium. Bacteriophage PL-1 and its host strain, Lactobacillus casei ATCC 27092, were used. Bacteria were grown in MR medium ( $\mathrm{pH} \mathrm{6.0)}$ at $37^{\circ} \mathrm{C}$, harvested by centrifugation in the early-exponential growth phase, washed twice, and resuspended in $50 \mathrm{~mm}$-Tris/maleate buffer ( $\mathrm{pH} \mathrm{6.0)}$ containing $10 \mathrm{mM}^{-\mathrm{CaCl}} \mathrm{Cl}_{2}$. MR medium ( $\mathrm{pH} \mathrm{6.0)} \mathrm{contained} \mathrm{(} \mathrm{g}$ per litre deionized water): polypeptone, 10; sodium acetate, 10 ; yeast extract, 3 ; beef extract, $3 ; \mathrm{NaCl}, 1 ; \mathrm{CaCl}_{2} .2 \mathrm{H}_{2} \mathrm{O}, 1.5 ; \mathrm{MgSO}_{4} .7 \mathrm{H}_{2} \mathrm{O}, 0.2 ; \mathrm{MnSO}_{4} \cdot \mathrm{H}_{2} \mathrm{O}, 0.01 ; \mathrm{FeSO}_{4} .7 \mathrm{H}_{2} \mathrm{O}, 1$; and 
Lectin

Canavalia ensiformis:

jack bean (Con A)

Lens culinaris:

lentil ( $\mathrm{LcH})$

Pisum sativum:

garden pea (PEA)

Glycine max:

soybean (SL)

Bauhinia purpurea:

mountain ebony (BPA)

Phaseolus lunatus:

lima bean (LBA)

Phaseolus vulgaris:

red kidney bean (PHA)

Helix pomatia:

edible snail (HPA)

Sophora japonica:

Japanese pagoda tree (SJA)

Wisteria floribunda:

Japanese wisteria (WFA)

Triticum vulgaris:

wheat germ (WGA)

Ricinus communis:

castor bean (RCA)

Streptomyces sp. 27S5

(SHA)
Table 1. Sugar binding specificity of lectins used

Binding sugar*

Reference

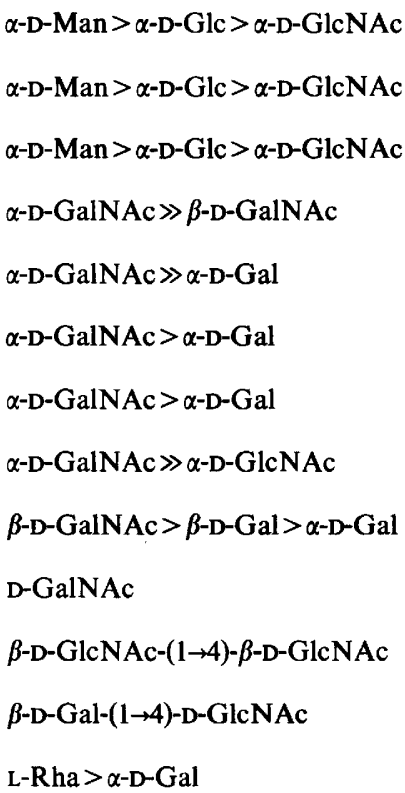

Sumner \& Howell (1936)

Howard \& Sage (1969)

Entlicher et al. (1970)

Liener (1958)

Irimura \& Osawa (1972)

Gould \& Scheinberg (1970)

Robbins (1964)

Hammarström \& Kabat (1969)

Osawa \& Akiya (1961)

Toyoshima et al. (1971)

Nagata \& Burger (1972)

Nicolson \& Blaustein (1972)

Fujita et al. (1973)

* Glc, glucose; Gal, galactose; Man, mannose; Rha, rhamnose; NAc, $N$-acetyl; $>$, more strongly than; 》 much more strongly than.

glucose, 10. Propagation of phage, their assay as p.f.u. $\mathrm{ml}^{-1}$, and other related methods have been described (Watanabe et al., 1970; Watanabe \& Takesue, 1975; Watanabe et al., 1977).

Chemicals. The origin of the lectins used in this study and their sugar-binding specificities are summarized in Table 1. The lectins Con A, SL and WGA were from Pharmacia and LcH, PEA, BPA, LBA, PHA, HPA, SJA and WFA from E. Y. Laboratories. SHA, an anti-human blood group B haemagglutinin produced by Streptomyces sp. 27S5, was prepared by the method of Fujita et al. (1973, 1975). RCA was kindly supplied by Dr G. Funatsu, Kyushu University. Phenyl $\alpha$-D-galactoside, methyl $\alpha$-D-glucoside, crude beef pancreas DNAase I and bovine pancreas RNAase A were from Sigma, and trypsin was from Merck.

Preparation of cell wall polysaccharide (PS) and peptidoglycan $(P G)$ fractions. Exponential phase $L$. casei cells suspended in an appropriate amount of deionized water were disrupted in a Dyno-Mill (type KDL, $150 \mathrm{ml}$ capacity) with $120 \mathrm{ml}$ glass beads $(0.1 \mathrm{~mm}$ diam.) for $2 \mathrm{~min}$ in the cold. The lysates were centrifuged at $1300 \mathrm{~g}$ for $10 \mathrm{~min}$ to remove the unbroken cells. The supernatants were again centrifuged, at $7500 \mathrm{~g}$ for $15 \mathrm{~min}$, to sediment the cell walls. The crude cell wall preparation was then suspended in $50 \mathrm{~mm}$-phosphate buffer $(\mathrm{pH} 7.6)$ and digested with DNAase $\left(5 \mu \mathrm{g} \mathrm{ml}^{-1}\right)$, RNAase $\left(0.5 \mathrm{mg} \mathrm{m}^{-1}\right)$ and trypsin $\left(0.5 \mathrm{mg} \mathrm{ml}^{-1}\right)$ for $1 \mathrm{~h}$ at $37^{\circ} \mathrm{C}$. Finally, they were washed with water and lyophilized. Electron microscopic examination showed the cell wall preparations to be free from unbroken cells. The cell walls $\left(300 \mathrm{mg}\right.$ ) were treated with $50 \mathrm{ml} 5 \%(\mathrm{w} / \mathrm{v}) \mathrm{TCA}$ at $90{ }^{\circ} \mathrm{C}$ for $15 \mathrm{~min}$, and, after being cooled, the mixture was centrifuged at $11000 \mathrm{~g}$ for $15 \mathrm{~min}$ to obtain the TCA-insoluble fraction enriched for peptidoglycan. The precipitate was washed first with $5 \%$ TCA and then thoroughly with deionized water; it was lyophilized and used as the PG preparation. Then, a ninefold volume of ethyl alcohol was added to the supernatant (TCA-soluble fraction), and left overnight at $4{ }^{\circ} \mathrm{C}$. The precipitate containing the polysaccharide (PS) was recovered by centrifugation, washed with ethyl alcohol and ether, and lyophilized.

Analytical methods. For quantitative determination of the constituent sugars, PS was hydrolysed at $100^{\circ} \mathrm{C}$ for $3 \mathrm{~h}$ with $3 \mathrm{M}-\mathrm{HCl}$ in a sealed glass tube. After evaporation in a rotary evaporator at $30^{\circ} \mathrm{C}$, the residue was dissolved in $0.15 \mathrm{M}$-borate buffer ( $\mathrm{pH} \mathrm{8.0)}$ ) for neutral sugars and in $0.2 \mathrm{M}$-citrate buffer ( $\mathrm{pH} \mathrm{2.2)}$ for amino sugars. Analysis of these sugars was carried out in a Hitachi 034 liquid chromatograph.

Assay of phage adsorption to L. casei cells and the effect of lectins. The exponential phase $L$. casei cells $\left(3 \times 10^{8}\right.$ cells $\mathrm{ml}^{-1}$ ), suspended in $50 \mathrm{~mm}$-Tris/maleate buffer ( $\mathrm{pH} 6.0$ ) containing $10 \mathrm{mM}-\mathrm{CaCl}_{2}$, were mixed with PL-1 phage at a multiplicity of infection (m.o.i.) of $5 \times 10^{-4}$ and incubated at $37^{\circ} \mathrm{C}$. At intervals, aliquots of the mixtures were withdrawn and centrifuged at $5000 \mathrm{~g}$ for $10 \mathrm{~min}$, and the cell-free supernatants were assayed for 
unadsorbed phage. For testing the effect of lectins on phage adsorption, the cells were preincubated with lectins at $37^{\circ} \mathrm{C}$ for $5 \mathrm{~min}$ before being mixed with phage, and the percentage of unadsorbed phage was compared with that of the control without lectins. The lectins used did not inactivate PL-1 phage.

Electron microscopy. A drop of the phage/PS or phage/PG mixture was placed on a copper grid coated with collodion/carbon film, and negatively stained with $2 \%(w / v)$ uranyl acetate. After removal of excess stain on the grid with filter paper, the specimens were examined in a JEOL $100-\mathrm{C}$ electron microscope at $80 \mathrm{kV}$.

\section{RESULTS}

Effect of polysaccharide on the adsorption of PL-1 phage to the host cell walls

PL-1 phage have been shown to adsorb specifically to isolated cell walls as well as to intact cells of $L$. casei (Watanabe et al., 1977, 1980). Because the outermost layer of the cell walls is polysaccharide (PS), this is the most likely phage receptor site. To obtain direct evidence for this, we examined whether the phage adsorption to the cell walls would be inhibited by preparations of PS free from peptidoglycan (PG). Cell walls were mixed with various concentrations of PS and then incubated with the phage at $37^{\circ} \mathrm{C}$ for $40 \mathrm{~min}$. As Table 2 shows, phage were rapidly adsorbed in the absence of added PS, so that the proportion of unadsorbed phage was $13.6 \%$ of input phage after incubation. In the presence of PS, however, the proportion of unadsorbed phage increased with increasing concentrations of PS, showing that the phage adsorption was inhibited by PS and that PS therefore contains receptor sites for PL-1 phage. There was no adsorption of phage to the PG preparation.

\section{Electron microscopic appearance of PL-1 phage mixed with polysaccharide or peptidoglycan}

PS material $\left(200 \mu \mathrm{g} \mathrm{ml}^{-1}\right)$ was incubated with approximately $6 \times 10^{10} \mathrm{PL}-1$ phage $\mathrm{ml}^{-1}$ at room temperature for $5 \mathrm{~min}$ in Tris/maleate buffer, and negatively stained with uranyl acetate. As Fig. $1(a, b)$ shows, phage particles appear to be aggregated when compared with the control (Fig. 1d) without PS. The phage were seen associated by their tail tip to fragments of PS material, which could not be characterized morphologically even by electron microscopy. The adsorbed phage appeared to be intact, with DNA present in the heads. In another control (Fig. $1 c$ ), where the phage were mixed with PG, the phage were uniformly dispersed in the same manner as without PG or PS.

\section{Chemical composition of polysaccharide}

Acid-hydrolysis of PS material yielded L-rhamnose, D-glucose, D-glucosamine and D-galactosamine in the approximate molar ratio of $4: 2: 1: 1$ (Table 3). Teichoic acid was not detected. The presence of $N$-acetyl residues in the PS was suggested by a strong absorption at $1650 \mathrm{~cm}^{-1}$, typical of the carboxamide group of hexosamines (detailed data not shown). On this basis it is possible that both the D-glucosamine and D-galactosamine of the native PS are $\mathrm{N}$-acetylated.

\section{Effect of lectins on $P L-1$ phage adsorption to cells}

PL-1 phage were incubated at $37^{\circ} \mathrm{C}$ for $15 \mathrm{~min}$ with host cells pretreated with various lectins, each at various concentrations, and the amounts of unadsorbed phage were assayed (Fig. 2). In a control without lectins, over $90 \%$ of the input phage were adsorbed. However, when the cells had been pretreated with SHA, which binds specifically to non-reducing terminal L-rhamnosyl residues, phage adsorption was much reduced, and the proportion of unadsorbed phage increased with increasing concentration of SHA. Con A, LcH and PEA, which are specific for Dmannose, D-glucose and $N$-acetyl-D-glucosamine, inhibited phage adsorption to some extent. However, the lectins SL, BPA, LBA, PHA, HPA, SJA, RCA and WGA, which bind specifically to $N$-acetyl-D-galactosamine or $N$-acetyl-D-glucosamine, had no effect on phage adsorption even at a concentration of $5 \mathrm{mg} \mathrm{ml}^{-1}$.

At the concentrations of SHA and Con A used here, no bacterial agglutination could be seen by the naked eye, although slight agglutination could be seen by phase-contrast microscopy. In order to test whether bacterial agglutination itself could reduce the probability of collision between the phage and their receptors, the following experiment was done. Host cells harvested and washed as described in Methods were resuspended in water and lyophilized. When the 

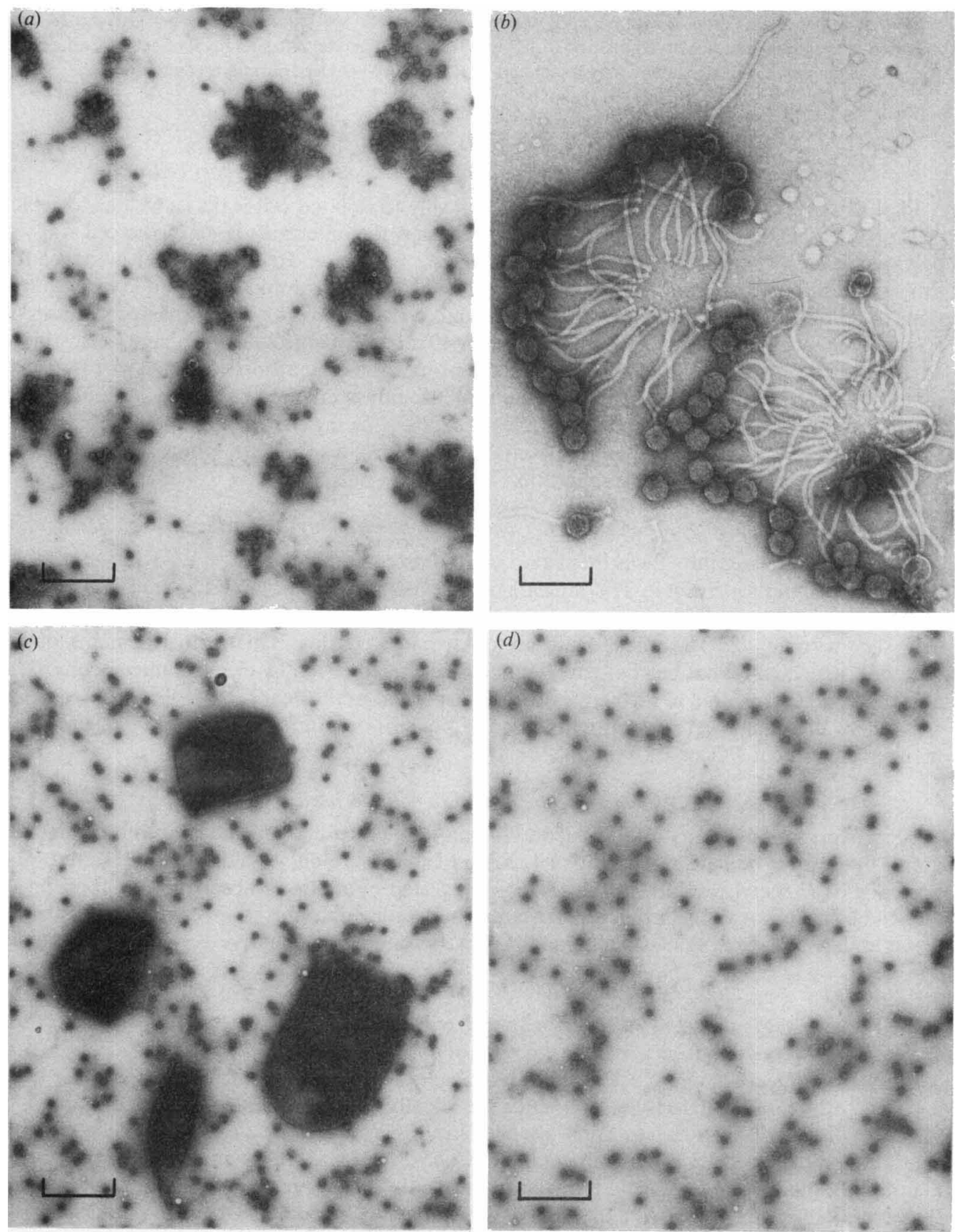

Fig. 1. Negatively stained phage PL-1 adsorbing to polysaccharide (PS) and peptidoglycan (PG). ( $a, b)$ Phage/PS mixture: (a) low magnification, bar marker represents $1 \mu \mathrm{m}$; $(b)$ higher magnification, bar marker represents $200 \mathrm{~nm}$. (c) Phage/PG mixture, bar marker represents $1 \mu \mathrm{m}$. (d) Phage without either PS or PG, bar marker represents $1 \mu \mathrm{m}$. Approximate concentrations: phage, $6 \times 10^{10} \mathrm{ml}^{-1}$; PS, $200 \mu \mathrm{g} \mathrm{ml}^{-1} ; \mathrm{PG}, 500 \mu \mathrm{g} \mathrm{ml}^{-1}$. 


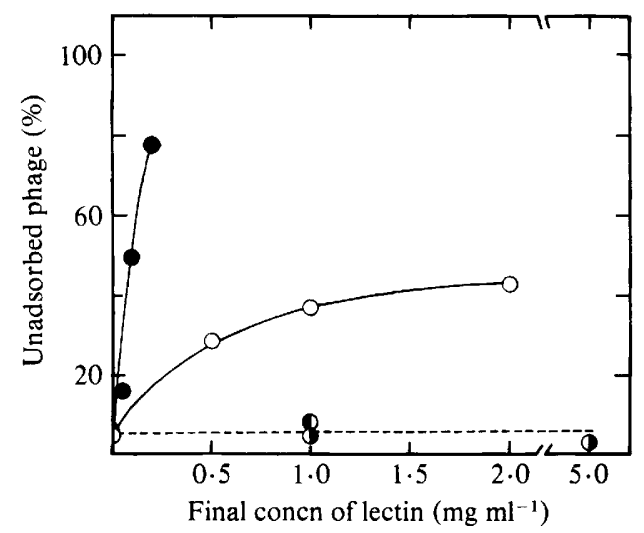

Fig. 2. Effect of various concentrations of different lectins on PL-1 phage adsorption to $L$. casei cells. Cells $\left(3 \times 10^{8} \mathrm{ml}^{-1}\right)$ were preincubated with various concentrations of lectins at $37^{\circ} \mathrm{C}$ for $5 \mathrm{~min}$. PL-1 phage were added at a m.o.i. of $5 \times 10^{-4}$, and incubation was continued for another $15 \mathrm{~min}$. The mixtures were centrifuged, and the proportion of unadsorbed phage in the supernatants was assayed. Lectins: $1 \mathrm{HA}$; $\mathrm{O}$, Con A; $\mathrm{O}$, WGA ; , BPA. Results are from three experiments.

Table 2. Effect of cell wall polysaccharide (PS) on PL-1 phage adsorption to L. casei cell walls

Cell walls $(\mathrm{CW})\left(10 \mu \mathrm{g} \mathrm{ml}^{-1}\right)$ or peptidoglycan fraction $(\mathrm{PG})\left(500 \mu \mathrm{g} \mathrm{ml}^{-1}\right)$ were incubated with PL-1 phage $\left(1.9 \times 10^{5} \mathrm{ml}^{-1}\right)$ in a Tris/maleate buffer $(\mathrm{pH} 6.0)$ at $37^{\circ} \mathrm{C}$ for $40 \mathrm{~min}$, and the proportion of unadsorbed phage was determined. The cell walls were mixed with various concentrations of PS for 5 min before the phage were added. Results are from three experiments.

$$
\begin{array}{ccc}
\text { Concn of PS } & \text { Unadsorbed phage } \\
\text { Components* } & \left(\mathrm{mg} \mathrm{ml} \mathrm{m}^{-1}\right) & (\%)
\end{array}
$$

$\begin{array}{lcc}\text { PL-1 phage } & 0.0 & 100 \cdot 0 \\ \text { CW + PL-1 phage } & 0.0 & 13.6 \\ \text { (CW + PS) + PL-1 phage } & 10 \cdot 0 & 60.5 \\ & 5 \cdot 0 & 28.2 \\ & 1.0 & 22.3 \\ & 0.1 & 15 \cdot 5 \\ & 0.01 & 13.7 \\ \text { PG + PL-1 phage } & 0.0 & 101.7\end{array}$

Table 3. Chemical composition of TCA-soluble fractions from L. casei ATCC 27092 cell walls

$\begin{array}{lcc}\text { Sugar } & \overbrace{\mu \mathrm{mol} \mathrm{\textrm {mg } ^ { - 1 }}}^{\text {Composition }} \\ & 2.32 & \text { Molar ratio } \\ \text { L-Rhamnose } & 1.14 & 4.03 \\ \text { D-Glucose } & 0.58 & 1.98 \\ \text { D-Glucosamine* } & 0.68 & 1.17 \\ \text { D-Galactosamine* } & 0.68\end{array}$

* Presumably $N$-acetylated form.

lyophilized cells were suspended in the Tris/maleate buffer, slight agglutination was seen by microscopy. However, PL-1 phage adsorption proceeded in the agglutinated cell suspensions in exactly the same manner as in unagglutinated ones. Therefore, it is most unlikely that cell agglutination played a role in the inhibition of phage adsorption by lectins.

Kinetics of lectin inhibition of $P L-1$ phage adsorption to cells

To examine more closely the inhibition of PL-1 phage adsorption to cells by SHA and Con A, a Lineweaver-Burk plot was constructed by plotting the reciprocal of the initial velocity of phage adsorption versus the reciprocal of the cell concentration in the presence of various con- 

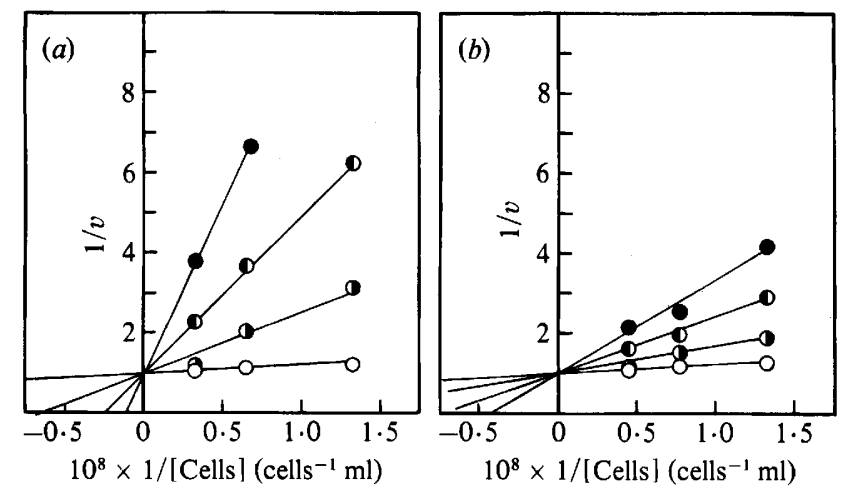

Fig. 3. Lineweaver-Burk plot showing competitive inhibition of the phage/cell interaction by SHA $(a)$ and Con $\mathbf{A}(b)$. Details of the assay are as described in the legend to Fig. 1. Concentrations of SHA (mg $\left.\mathrm{ml}^{-1}\right): 0,0.2 ; 0,0.1 ; 0,0.05 ; \mathrm{O}, 0.0$ (control). Concentrations of Con A $\left(\mathrm{mg} \mathrm{ml}^{-1}\right): \bigcirc, 2.0 ; 0,1.0$; 0,$0 ; 0,0 \cdot 0$ (control). Results are from three experiments.

centrations of lectins. The adsorption velocity $(v)$ was taken as the reduction in percentage of unadsorbed phages after 15 min incubation. As Figs $3(a)$ and $(b)$ show, the inhibition of phage adsorption to cells by these lectins was affected by the concentrations of both cells and lectin. As the cell concentration was increased, there was a decrease in the ability of lectins to inhibit phage adsorption. In the plot, the slope of the line became progressively steeper as the concentration of lectins was increased. However, all the intercept values on the ordinate $(1 / v)$ were almost the same as that of the control without lectins, in both the cases. Thus, the inhibitory pattern of these lectins displayed competitive characteristics. The $K_{\mathrm{m}}$ at each concentration of lectins was calculated from the negative intercept values on the abscissa. The $K_{\mathrm{m}}$ value at SHA of $0.2 \mathrm{mg} \mathrm{ml}^{-1}$ was $8.5 \times 10^{8}$ cells ml-1, and that at Con $A$ of $0.5 \mathrm{mg} \mathrm{ml}^{-1}$ was $1.5 \times 10^{7}$ cells $\mathrm{ml}^{-1}$, indicating that SHA binds more strongly to cells than Con A.

\section{Effect of the time of addition of lectins on PL-1 phage adsorption}

Figure 4 shows the effect of SHA on the kinetics of PL-1 phage adsorption to cells in Tris/maleate buffer. In a control without SHA, the proportion of unadsorbed phage decreased rapidly, and after $10 \mathrm{~min}$ incubation it was below $30 \%$ under the conditions used. The addition of SHA after $15 \mathrm{~min}$ incubation resulted in an immediate increase to approximately $60 \%$ in the proportion of free phage, showing that SHA is able to cause an immediate desorption of the previously adsorbed phage. However, the amount of phage that could be desorbed upon SHA treatment gradually declined as incubation continued (data not shown).

Figure 5 shows the results of a similar experiment using Con A instead of SHA. When Con A was added after $15 \mathrm{~min}$ incubation, again an immediate desorption of infectious phage occurred, while after a prolonged exposure to phage, Con A treatment was unable to release infectious phage. These results indicate that, as the incubation continues, the forces of phage adsorption, which are initially reversible, gradually become irreversible.

\section{Reversibility of lectin inhibition}

With the same experimental design, it was also possible to test whether the inhibitory action of these lectins on phage adsorption was reversible. Phenyl galactoside, one of the competitive inhibitors of SHA, was added to the mixture of cells, SHA and phage after 5 min incubation. The addition of phenyl galactoside (Fig. 4) resulted in partial reversion of phage adsorption, although such a quick and complete phage adsorption as seen without lectins was not observed under the conditions used. Phenyl galactoside itself had no effect on phage adsorption. These results indicate that the binding of SHA to cells is partially reversible and that the inhibition of phage adsorption by SHA is due to the specific interaction of SHA with sugar residues on the cell surface. However, after prolonged exposure to SHA, the cells became gradually unable to desorb 


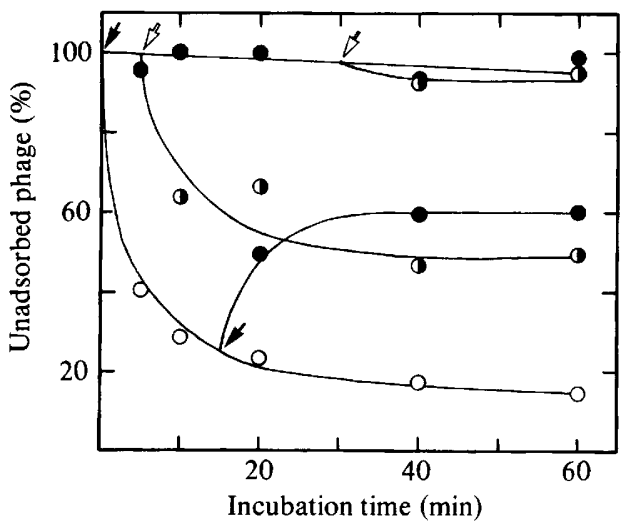

Fig. 4

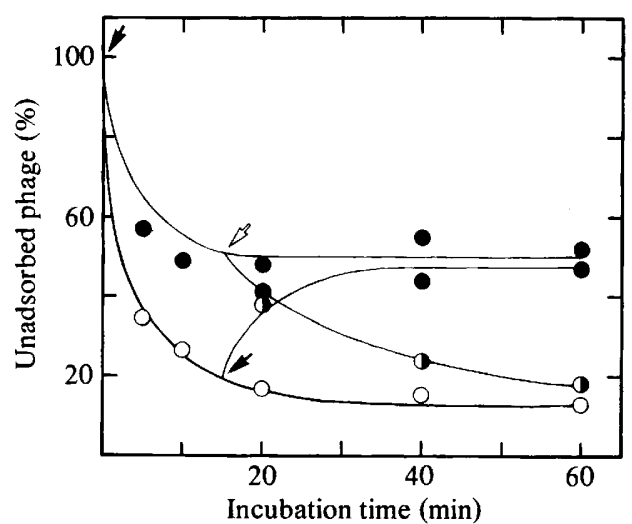

Fig. 5

Fig. 4. Effect of SHA on the kinetics of PL-1 phage adsorption. The reaction mixtures contained $\left(\mathrm{ml}^{-1}\right): 1.5 \times 10^{8}$ cells, $0.2 \mathrm{mg} \mathrm{SHA}, 7.5 \times 10^{5}$ p.f.u. phage and $2 \mathrm{mg}$ phenyl galactoside. At the times indicated, samples were taken to determine the proportion of unadsorbed phage. $O$, Phage adsorption to untreated cells (control); $\bigcirc$, SHA added to adsorption mixture at 0 and 15 min (filled arrows); $($, SHA added to adsorption mixture at zero time, and phenyl galactoside added 5 and 30 min later (open arrows). Results are from four experiments.

Fig. 5. Effect of Con A on the kinetics of PL-1 phage adsorption. The reaction mixtures contained $\left(\mathrm{ml}^{-1}\right): 1.4 \times 10^{8}$ cells, $1 \mathrm{mg}$ Con A, $7.5 \times 10^{5}$ p.f.u. phage, and $1 \mathrm{mg}$ methyl glucoside. At the times indicated, samples were taken to determine the proportion of unadsorbed phage. $O$, phage adsorption

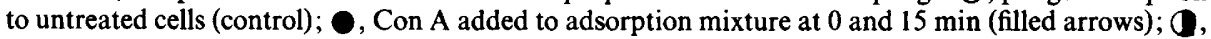
Con $\mathrm{A}$ added to adsorption mixture at zero time, and methyl glucoside added 15 min later (open arrow). Results are from seven experiments.

SHA on addition of phenyl galactoside (compare desorption values when phenyl galactoside was added after $30 \mathrm{~min}$ and $5 \mathrm{~min}$ incubation, Fig. 4). The inhibition of phage adsorption by Con $\mathrm{A}$ was also reversed by the addition of a competitive inhibitor, methyl glucoside (Fig. 5).

\section{DISCUSSION}

Several lectins have been shown to interact in a highly specific way with defined polysaccharides on the surface of a variety of cells. Therefore, they have been successfully used as a tool for obtaining structural information on the presence of specific sugars, the configuration of anomeric linkages and the position of sugar residues, e.g. in phage receptor sites (Archibald \& Coapes, 1972; Birdsell \& Doyle, 1973; Watanabe \& Shiomi, 1976; Picken \& Beacham, 1977). We have studied the interaction of phage PL-1 with its host, L. casei, which has a cell wall polysaccharide consisting of only L-rhamnose, D-glucose, D-glucosamine and D-galactosamine (these hexosamines may be present in $\mathrm{N}$-acetylated form). The availability of lectins specific for these compounds prompted us to examine the effect of such lectins on the adsorption of PL-1 phage to the cells in order to obtain indirect evidence of the role of these sugars in the binding of phage. We found that both SHA, which binds specifically to L-rhamnose, and Con A, LcH and PEA, which bind to D-glucose and $N$-acetyl-D-glucosamine, inhibited phage adsorption. However, lectins specific to $N$-acetyl-D-glucosamine or $N$-acetyl-D-galactosamine only were not effective, suggesting that these hexosamines might not be critical determinants in the phage receptor sites.

The inhibition of phage adsorption by SHA and Con A was rapid, occurring almost immediately upon their addition to the mixtures of cells and phage. The interaction between these lectins and cells effected no permanent changes in the cell surface; almost immediately after the addition of the lectin inhibitor phenyl galactoside to SHA/cell mixtures or methyl glucoside to Con $\mathrm{A} /$ cell mixtures, phage adsorption resumed.

Among the lectins tested, the most effective inhibitor was SHA. It has a specificity for nonreducing terminal L-rhamnose and the configuration of the hydroxy groups at C-2 and C-4 is 
essential for binding (Fujuita et al., 1973; 1975). Therefore, it is concluded that an L-rhamnosyl residue is a major determinant in the PL-1 phage receptor site. Con A inhibited the phage adsorption, but to a lesser extent than SHA. Con A binds specifically to $\alpha$-linked, non-reducing D-glucose and $N$-acetyl-D-glucosamine residues and is considered to interact with unmodified hydroxyl groups at the C-3, C-4 and C-6 positions of the pyranose ring (Goldstein \& Iyer, 1966). Methylation analysis of the isolated polysaccharide yielded 2,3,4-tri- $O$-methyl-L-rhamnose and 2,3,4,6-tetra- $O$-methyl-D-glucose in addition to other, unidentified, sugars (unpublished data), suggesting that both these sugar residues occupy non-reducing terminal positions in the cell wall polysaccharide. However, the phage PL-1 appears to bind primarily to L-rhamnose. The lower degree of inhibition by Con A may indicate that the glucosyl residue also participates in the binding; alternatively, the binding of the lectin close enough to the phage binding site may prevent its binding by its steric hindrance.

This work was supported in part by research-aid funds both from the Japan Private School Promotion Foundation and the Mishima Kai-un Memorial Foundation. We also thank the following students of Fukuoka University for their technical assistance in some of the experiments: A. Tachifuji, R. Kobayashi, R. Fujimoto, S. O-yama and T. Nanri.

\section{REFERENCES}

ACKerman, H. W. \& EISENSTARK, A. (1974). The present state of phage taxonomy. Intervirology 3, 201-209.

ARCHIBALD, A. R. \& COAPES, H. E. (1972). Blocking of bacteriophage receptors by concanavalin A. Journal of General Microbiology 73, 581-585.

Birdsell, D. C. \& Doyle, R. J. (1973). Modification of bacteriophage $\phi 25$ adsorption to Bacillus subtilis by concanavalin A. Journal of Bacteriology 113, 198202.

Choy, Y. M., Wong, S. L. \& LeE, C. Y. (1979). Change in surface carbohydrate-binding proteins of plants and animals. Carbohydrate Chemistry and Biochemistry 35, 127-340.

DOYLE, R. J. \& BIRDSELL, D. C. (1972). Interaction of concanavalin A with the cell wall of Bacillus subtilis. Journal of Bacteriology 109, 652-658.

ENTLICHER, G., KošTIŘ, J. V. \& KoCAUREK, J. (1970). Studies on phytohemagglutinins. III. Isolation and characterization of hemagglutinins from the PEA. Biochimica et biophysica acta 221, 272-281.

Fujita, Y., OISHI, K. \& AIDA, K. (1973). Sugar specificity of anti-B hemagglutinin produced by Streptomyces sp. Biochemical and Biophysical Research Communications 53, 495-501.

Fujita, Y., Oishi, K., SuzuKi, K. \& Imahori, K. (1975). Purification and properties and an anti-B hemagglutinin produced by Streptomyces sp. Biochemistry 14, 4465-4470.

Goldstein, I. J. \& HAYES, C. E. (1978). The lectins: carbohydrate-binding proteins of plants and animals. Advances in Carbohydrate Chemistry and Biochemistry 35, 127-340.

GOLDSTEIN, I. J. \& IYER, R. N. (1966). Interaction of concanavalin A, a phytohemagglutinin, with model substrates. Biochimica et biophysica acta 121, 197200.

Goldstein, I. J. \& MisaKI, A. (1970). Interaction of concanavalin A with an arabinolactan from the cell wall of Mycobacterium bovis. Journal of Bacteriology $103,422-425$.

Goldstein, I. J. \& STAUB, A. M. (1970). Interaction of concanavalin A with polysaccharides of Salmonella. Immunochemistry 17, 315-319.

Gould, N. R. \& SCHEINBERG, S. L. (1970). Isolation and partial characterization of two anti-A hemagglutinins from $P$. lunatus. Archives of Biochemistry and Biophysics 137, 1-11.

Hamada, S., Gill, K. \& Slade, H. D. (1977). Binding of lectins to Streptococcus mutans cells and type-specific polysaccharides, and the effect on adherence. Infection and Immunity 18, 708-716.

Hammarström, S. \& Kabat, E. A. (1969). Purification and characterization of a blood-group $A$ reactive hemagglutinin from the snail Helix pomatia and a study of its combining site. Biochemistry 8, 26962705.

HowarD, I. K. \& SAGE, H. J. (1969). Isolation and characterization of a phytohemagglutinin from the lentil. Biochemistry 8, 2436-2441.

IRIMURA, T. \& OsAWA, T. (1972). Studies on a hemagglutinin from Bauhinia purpurea alba seeds. Archives of Biochemistry and Biophysics 151, 475-482.

LIENER, I. E. (1958). Inactivation studies on the soybean hemagglutinin. Journal of Biological Chemistry 233, 401-405.

LIENER, I. E. (1976). Isolation and properties of concanavalin A. In Concanavalin A as Tool, pp. 17-31. Edited by H. Bittiger \& H. P. Schneble. London: John Wiley.

NAGATA, Y. \& BuRger, M. M. (1972). Wheat germ agglutinin. Isolation and crystallization. Journal of Biological Chemistry 247, 2248-2250.

Nicolson, G. \& Blaustein, J. (1972). The interaction of Ricinus communis agglutinin with normal and tumor cell surfaces. Biochmica et biophysica acta 266, 543-547.

Osawa, T. (1975). Lectins (in Japanese). Kagaku To Seibutsu 13, 273-280.

OsAWA, T. \& AKIYA, S. (1961). Immunochemical studies on blood-group specificity. I. Partial purification and properties of plant agglutinin (lectin) of Sophora japonica. Bulletin of Tokyo Medical and Dental University 8, 287-298. 
Picken, R. N. \& Beacham, I. R. (1977). Bacteriophage-resistant mutants of Escherichia coli K12 with altered lipopolysaccharide. Studies with concanavalin A. Journal of General Microbiology 102, 319-326.

ReEder, W. J. \& Ekstedt, R. D. (1971). Study of the interaction of concanavalin A with Staphylococcol teichoic acids. Journal of Immunology 106, 334-340.

Robrins, J. H. (1964). Tissue culture studies of the human lymphocyte. Science 146, 1648-1654.

SHARON, N. \& LIS, H. (1972). Lectins: cell-agglutinating and sugar-specific proteins. Science 177, 949959.

Sumner, J. B. \& Howell, S. F. (1936). The identification of the hemagglutinin of the jack bean with concanavalin A. Journal of Bacteriology 32, 227-237.

Toyoshima, S., Akiyama, Y., Nakano, K., TonoMURA, A. \& OSAWA, T. (1971). A phytomitogen from Wisteria floribunda seeds and its interaction with human peripheral lymphocytes. Biochemistry 10 , $4457-4463$.
Watanabe, T. \& SHIomi, T. (1976). Effect of plant lectins on $\gamma$-phage receptor sites of Bacillus anthracis. Japanese Journal of Microbiology 20, 147-149.

Watanabe, K. \& TaKesue, S. (1975). Use of L-rhamnose to study irreversible adsorption of bacteriophage PL-1 to a strain of Lactobacillus casei. Journal of General Virology 28, 29-35.

Watanabe, K., Takesue, S., Jin-Nal, K. \& YoSHIKAWA, T. (1970). Bacteriophage active against the lactic acid beverage-producing bacterium, Lactobacillus casei. Applied Microbiology 20, 409-415.

Watanabe, K., Takesue, S. \& Ishibashi, K. (1977). Reversibility of the adsorption of bacteriophage PL-1 to the cell walls isolated from Lactobacillus casei. Journal of General Virology 34, 189-194.

Watanabe, K., Takesue, S. \& Ishibashi, K. (1980). Electron microscopic studies on the interaction between Lactobacillus phage PL-1 and cell walls isolated from its host cells. Journal of General and Applied Microbiology 26, 413-420. 